\title{
SETTING UP A PROBLEM OF AIR-BORNE SOUND INSULATION CALCULATION FOR DOUBLE LAYER MASSIVE ENCLOSURES ON THE BASE OF THE MODELS WITH THE CONCENTRATED PARAMETERS
}

\author{
Arkadiy V. Zakharov, Ivan P. Saltykov \\ National Research Moscow State University of Civil Engineering, Moscow, RUSSIA
}

\begin{abstract}
The calculation methods on the base of the concentrated parameters models, which were formed in the XX century, allowed to get simple and theoretically consistent solutions for the problems of one-layered building partitions sound insulation finding. The sound insulation estimation for the double-layered massive building partitions also is of scientific and practical interest, as double layer partitions are the particular case of the single layer enclosure's application. The concept of concentrated parameters includes the concentrated and the reduced masses, as well as the concentrated elasticity. The criteria for the object application as a specified kind of the concentrated parameters in the acoustical problems is the presence or the absence of the oscillation movement in it. The three calculation models with the application of the concentrated (discreet) parameters that to define the sound insulation of the massive double layer enclosures are given. The equations for sound insulation computation for one layer partition are represented. They were derived on the base of momentum law and energy conservation formulas under the continuity of energy flow conditions at the interface of different media. The three main paths of sound propagation from the room with the air-borne noise to the isolated room are shown. The two frequency range are separated on the way of the direct sound propagation: at the first, the surface density of the one of two layers and the air elasticity in the inter-layer gap influence on isolation; at the second one, the predominant role belongs to the summarized insulation by the "Mass Action Law" of the two layers. The indirect way's insulation is taken in account through the additional sound insulation graph drawing. The compound insulation curve is defined by the ways, where the sound energy transmittance is maximal at the standard frequency spectrum. The method of sound insulation calculation for the double layer partitions on the base of the concentrated parameters model application is revealed. As an example, the calculation of a prefabricated double layer inter-flat wall in the panel building was performed.
\end{abstract}

Keywords: limit frequency, sound insulation of the double layer massive partitions, discreet parameters, reduced mass, concentrated mass, concentrated elasticity, "Mass Action Law", coefficient of the oscillation velocity transmittance, free oscillation frequency, wave resonances

\section{ПОСТАНОВКА ЗАДАЧИ РАСЧЁТА ЗВУКОИЗОЛЯЦИИ ВОЗДУШНОГО ШУМА ДВУХСЛОЙНЫМИ МАССИВНЫМИ ОГРАЖДЕНИЯМИ НА ОСНОВЕ МОДЕЛЕЙ С СОСРЕДОТОЧЕННЫМИ ПАРАМЕТРАМИ}

\footnotetext{
А.В. Захаров, И.П. Салтыков

Национальный исследовательский Московский государственный строительный университет, г. Москва, РОССИЯ

\begin{abstract}
Аннотация. Созданные в конце XX века расчётные методики на основе использования моделей с сосредоточенными параметрами позволили получать простые и теоретически не противоречивые решения задач по нахождению звукоизоляции однослойных строительных перегородок. Нахождение звукоизоляции двойных массивных строительных перегородок, частного случая использования однослойных звукоизолирующих преград, также представляет научный и практический интерес. Под понятием сосредоточенных параметров подразумеваются сосредоточенная и приведённая массы, а также, сосредоточенная упругость. Критерием использования объекта в акустических задачах в качестве того или иного вида сосредоточенных параметров в заданном частотном диапазоне является отсутствие или наличие в нём волнового движения. Приведены три расчётные модели с использованием сосредоточенных (дискретных) параметров необходимые для вычисле-
\end{abstract}


ния звукоизоляции двухслойных массивных перегородок. Представлены выражения для нахождения звукоизоляции однослойных перегородок, полученные на основе применения уравнений сохранения количества движения и кинетической энергии с учётом свойств непрерывности передачи звуковой энергии на границе различных сред. Показаны основные пути распространения звука из помещения с источником в изолируемое помещение. При расчёте звукоизоляции по прямому пути выделяются два частотных диапазона: в первом, влияние на звукоизоляцию оказывает поверхностный вес одного из слоёв и упругость воздуха в воздушном промежутке; во втором определяющее значение играет суммарная звукоизоляция по закону «массы» каждого из слоёв. Звукоизоляция на косвенных путях распространения звука учитывается через построение графика добавочной звукоизоляции. Результирующий график звукоизоляции определяется теми путями, где возможно максимальное прохождение звука в нормируемом частотном диапазоне. Дана методика расчёта звукоизоляции массивных двойных строительных перегородок на основе применения моделей с сосредоточенными параметрами. В качестве примера, выполнен расчёт сборной двойной межквартирной стены в панельном здании.

Ключевые слова: предельная частота, звукоизоляция двухслойных массивных перегородок, дискретные параметры, приведённая масса, сосредоточенная масса, сосредоточенная упругость, закон «массы», коэффициент прохождения колебательной скорости, частота свободных колебаний, волновые резонансы

\section{INTRODUCTION}

The theory and the methods of practical engineer solutions for the sound insulation problems of envelope building constructions are permanently developing and improving, that is confirmed by the scope of nowadays issues on this topic [1-6]. The theory of the sound insulation calculation on the base of concentrated (discreet) parameters, which was founded at the end of the XX century is the one from their contemporary range.

As it is shown in papers [7-17], the calculation methods, that are based on the fundamental concepts of this theory, give the consistent, close to experiment, results for the computation of the single-layered building partitions sound insulation. Besides, some essential problems of building acoustics were managed to revise in the frame of this approach, for instance, such as insulation's value dependence from the noise incidence angle at the plate, the spatial and frequency resonances existence, and the internal friction coefficient's influence on the enclosure's insulation.

A particular case for the massive single-layered building partitions application is the doublelayered sound protective structures for the purpose of acoustic comfort level increasing at the isolatable premises. Along with such decisions, the massive walls and partitions constructions, which have two rigid and shape generating strata divided by the air gap, are often provided.

The evaluation of a similar enclosure's insulation accordingly the classical sound insulation theory is theoretically and practically complicated, that's why the normative codes represent it in a mere approximation. Therefore, it seems interesting to set a task and to develop an algorithm for the engineering computation of massive double layered partitions on the basis of the physical models with the concentrated parameters.

\section{MATERIALS AND METHODS}

The problem of the calculation graph's obtaining for the double-layered massive envelopes is compounded by the impact of the indirect noise propagation paths through the contiguous structures. The three main paths of sound propagation in an insulated room can be derived in case of observing calculation model, fig. 1: A - is the direct way of sound transmittance through the double enclosure; $\mathrm{B}$ - is the sound transmittance through the rigid layers and the floor slab; $\mathrm{C}-$ is the sound propagation through the floor slab only. The real measurement's practice shows, that the sound insulations values by the way of the maximal sound propagation energy in a isolatable unit should be taken into consideration. 


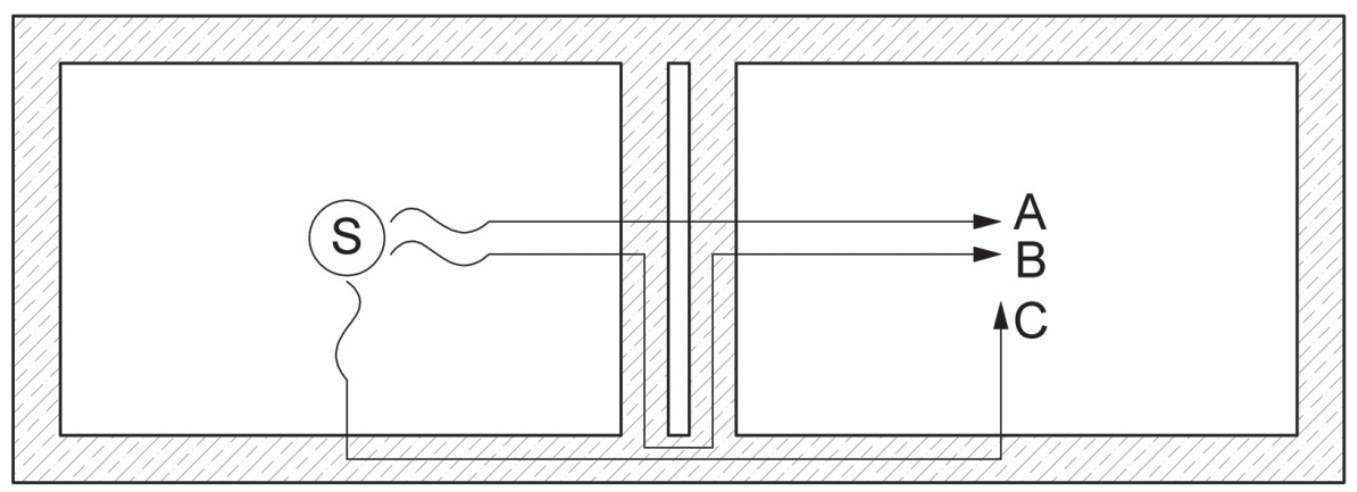

Figure 1. The sound propagation paths from the room with the source $(S)$ in the protectable room: $A$ - is the way of direct propagation; $B$ and $C$-are the way of indirect transmittance through the adjoining constructions

The papers $[10,13,15,17]$ inform, that the objects can be either the environment for the wave moving's transmittance, that way they become to be "waveguides", or can be represented in the capacity of "concentrated masses" or "concentrated elasticity bodies". The criteria of construction's transition from the working in a "mass" or "elasticity" regime to the regime of a "waveguide" is written by the equation (1):

$$
f_{\text {ult. }}=\frac{c}{2 \pi l}, \mathrm{~Hz}
$$

where $f_{\text {ult. }}$ - is an ultimate oscillation frequency, $\mathrm{Hz}$, above which the wave movement can't be avoided; $l-$ is the dimension of an object, along which the sound wave propagates, $[\mathrm{m}] ; c-$ is the propagation velocity of the definite wave type in the object, $\left[\mathrm{m} \cdot \mathrm{s}^{-1}\right]$.

Thus, under the condition of $f<f_{\text {ult. }}$ a body is taken into account as the concentrated mass, which is defined by the surface density, $\mathrm{m},\left[\mathrm{kg} \cdot \mathrm{m}^{-2}\right]$; or it can be taken as the concentrated elasticity, which is characterized by the elastic ratio, $\mathrm{K},\left[\mathrm{N} \cdot \mathrm{m}^{-1}\right]$. At the range of $f>f_{\text {ult. }}$, the body becomes to be a guide to the mechanical waves, and, as it follows from the papers $[9,10,13,15]$, is denoted through the so called "reduced mass", $\mu$, in the acoustical tasks. The reduced mass is inherently the mass fragment, that is limited by the wave length $\lambda$ and multiplied on the reduction factor $\left[1 \cdot(2 \pi)^{-1}\right]$ :

$$
\mu=\frac{\rho \cdot \lambda}{2 \pi}=\frac{\rho \cdot c}{2 \pi f},\left[\mathrm{~kg} \cdot \mathrm{m}^{-2}\right],
$$

where $\rho-$ is the medium density, $\left[\mathrm{kg} \cdot \mathrm{m}^{-3}\right] ; c$ and $\lambda$ - are the propagation velocity, $\left[\mathrm{m} \cdot \mathrm{s}^{-1}\right]$, and the wave length of given form (dilatational, flexural or shear), [m]; $f$ - is the oscillation frequency, [Hz]. Different combinations of introduced objects are possible by the way of a sound waves propagation in the acoustical problems. The figure 3 shows the most typical schemes of the sound propagation in double layer enclosures at the figure 2 .

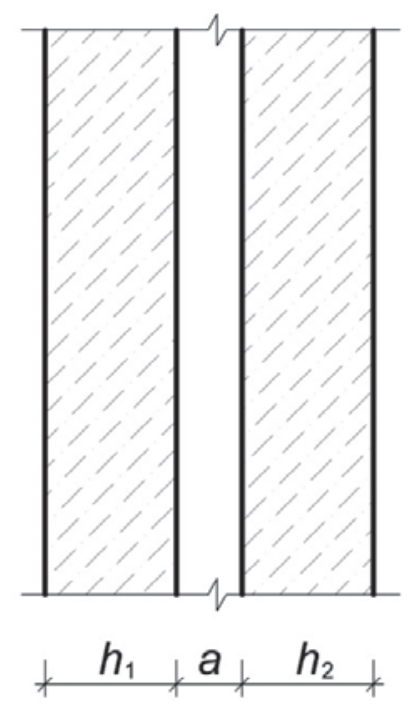

Figure 2. The scheme of a double layer massive partition 
a)

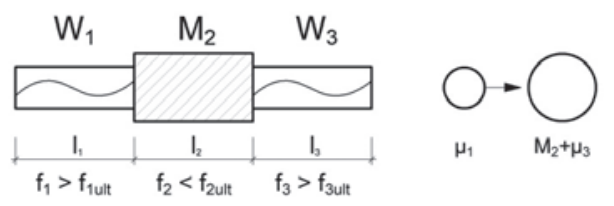

b)

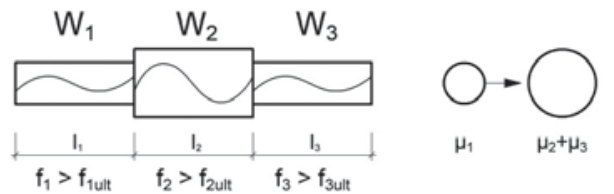

c)

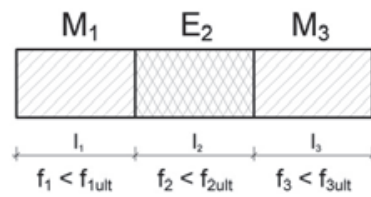

Figure 3. The schemes and the calculation models (at the right) with the concentrated parameters concerning to this issue: $a$-is waveguide $\left(W_{1}\right)$ mass $\left(M_{2}\right)$-waveguide $\left(W_{3}\right) ; b$-is waveguide $\left(W_{1}\right)$-waveguide $\left(W_{2}\right)$-waveguide $\left(W_{3}\right) ; c-i s$ mass $\left(M_{1}\right)$-elasticity $\left(E_{2}\right)$-mass $\left(M_{3}\right) ; \mu_{1}, \mu_{2}, \mu_{3}-$ are the reduced masses of the objects; $K$-is the elastic ratio for the resilient layer

As it is described at the [10,12, 13, 14, 17], it becomes possible to apply the momentum conservation law and the energy conservation law in acoustical processes after the introducing of concentrated parameters and under the condition of energy flow continuing at the interface of two media. Then, the scheme "a", figure 3, is applicable to the one-layered partition at the frequency range before so called "a wave coincidence phenomenon" $[18,19]$ : the air at the both sides of the structure is represented by the reduction masses $\mu_{1}, \mu_{3}$ and the partition is a concentrated mass $M_{2}$. The reduction mass of the air virtually strikes both the concentrated mass of the envelope and the reduction mass of the air over it.

Mathematically it can be written in the form of the equations (3) and (4) with the application of unit velocity and coefficients of sound transmittance and reflection:

$$
\begin{aligned}
& \mu \cdot v=\mu \cdot v \cdot \beta+(\mu+m) \cdot v \cdot \alpha ; \\
& \frac{\mu \cdot v^{2}}{2}=\frac{\mu \cdot(\beta v)^{2}}{2}+\frac{(\mu+m) \cdot(\alpha v)^{2}}{2}
\end{aligned}
$$

where $v$ - is the unite velocity of the media fragment movement; $\beta$-is the reflection coefficient of energy from the media fragment action on the plate surface; $\alpha$ - is the transmission coefficient of energy propagation into the plate from the moving media fragment; $\mu$ - is the reduction mass (in this case of the air); $m$ - concentrated mass (of the building envelope).

The solution of this system gives the transmission coefficient of the oscillation velocity, $\alpha$ :

$$
\alpha=\frac{2 \mu}{2 \mu+m}
$$

Then, according to the physical definition of the sound insulation, the equation (6) is derived. And it's form is very close to the formula of the "Mass Action Law":

$$
\begin{array}{r}
R_{\text {M.A.L. } 1}=10 \lg \frac{1}{\alpha^{2}}=10 \lg \left(1+\frac{m}{2 \mu_{a}}\right)^{2}=10 \lg \left(1+\frac{\pi m}{\rho_{0} \lambda_{0}}\right)^{2}= \\
=10 \lg \left(1+\frac{\pi m f}{\rho_{0} c_{0}}\right)^{2},[\mathrm{~dB}] ;
\end{array}
$$

where $\alpha$ - is the transmission coefficient of the oscillation velocity into the plate; $f$-is the current frequency, $[\mathrm{Hz}] ; m-$ is the surface density of the plate, $\left[\mathrm{kg} \cdot \mathrm{m}^{-2}\right] ; \rho_{0}-$ is the air specific weight, $\left[\mathrm{kg} \cdot \mathrm{m}^{-3}\right] ; c_{0}-$ is the sound speed in the air, $\left[\mathrm{m} \cdot \mathrm{s}^{-1}\right]$; $\mu_{a}-$ is the reduced mass of an air, $\left[\mathrm{kg} \cdot \mathrm{m}^{-2}\right]$.

After the wave coincidence frequency, $f_{L}$, the partition is working by the scheme " $b$ " in the figure 3: the air from both partition sides is also represented as the masses $\mu_{1}$ and $\mu_{3}$, and the partition becomes to be the "waveguide" with the reduction mass $\mu_{2}$. This time, the reduction mass of the air virtually strikes both the reduction mass of the envelope and the reduction mass of the air over it. After the similar form of the system consisting from the momentum conservation law and the energy conservation equations, the formula (7) is obtained. It characterizes the sound insulation by the "Mass Action Law" after the wave coincidence frequency.

$$
\begin{array}{r}
R_{\text {M.A.L. } 2}=10 \lg \frac{1}{\alpha^{2}}=10 \lg \left(1+\frac{\mu_{p l .}}{2 \mu_{a}}\right)^{2}= \\
=10 \lg \left(1+\frac{f m}{2 \rho_{0} c_{0}}\right)^{2},[\mathrm{~dB}] ;
\end{array}
$$


Setting Up a Problem of Air-Borne Sound Insulation Calculation For Double Layer Massive Enclosures on the Base of the Models With the Concentrated Parameters

where $\mu_{p l}-$ is the reduced mass of the partition material, $\left[\mathrm{kg} \cdot \mathrm{m}^{-2}\right]$.

The equations (6) and (7) allow to find sound insulation values at the two conventionally distinguishing frequency ranges of the standard spectrum. The third range begins from the frequency of $65[\mathrm{~dB}]$ in the engineer designs. The shear and the dilatational waves play a predominant role here for insulation defining, against the flexible waves at the previous ranges. Accordingly the normative documents, the graph is shown as a horizontal straight line at the third frequency range.

It is well known, that the resonance phenomena have an influence on the insulation figures at the definite frequencies. The resonances appear each times, when the integer number of semi-length flexible waves place by the length or by the width of the isolating plate. The resonance correction can be taken near $6[\mathrm{~dB}]$ in average during the engineer calculation performing. The simple formulas (8), (9) are derived in case of air environment, minus resonance corrections, from the formulas (6), (7) respectively, that to draw the insulation graphs.

$$
\begin{aligned}
& R_{\text {M.A.L.1 }}=20 \lg m f-48,[\mathrm{~dB}] \\
& R_{\text {M.A.L.2 }}=20 \lg m f-58,[\mathrm{~dB}] .
\end{aligned}
$$

Let's consider the noise propagation by the path "A". The masses of the separate layers and the elasticity of air between them make their contribution to the insulation values simultaneously. Accordingly the criteria (1), there will not be the oscillation movement in the air gap at the low and the middle frequencies, so, up to the ultimate air oscillation frequency in the gap, $f_{\text {ult.a. }}$, the sound insulation on the direct way will contain the sum of insulation by the model "a" or "b" (depending from the wave coincidence frequency for the several layers) and the insulation by the model "c" in figure 3 , formula (10):

$$
R_{\mathrm{I}}^{\mathrm{A}}=R_{\text {M.A.L. }}+R_{a} ;[\mathrm{dB}] ;
$$

where $R_{\text {M.A.L. }}$ - is the sound insulation value by equation (8) or (9), [dB], and that, only the mass the most thick layer is taken into consideration due to the instantaneity of the movement transmittance through the all layers; $R_{a}$-is the sound insulation by the formula (11), [dB].

$$
R_{a}=20 \lg \left|1-\left(\frac{\mathrm{f}}{f_{0}}\right)^{2}\right|,[\mathrm{dB}] ;
$$

where $f_{0}$ - is the free oscillation frequency of the system, [Hz], by equation (12):

$$
f_{0}=\frac{60}{\sqrt{a}} \cdot \sqrt{\frac{m_{1}+m_{2}}{m_{1} \cdot m_{2}}} ; \quad[\mathrm{Hz}] ;
$$

where $a$-is the width of an air gap, [m]; $m_{1}$ and $m_{2}$ - are the surface densities of the first and the second layers respectively.

At the range of $f>f_{\text {ult.a. }}$ the oscillation movement in an air gap begins and the model "c" fall into two sequentially working models "a" or "b" depending of the coincidence frequency value of the layers. Thereafter, the equation (13) will be applied at the conveniently second frequency range of the path "A":

$$
R_{\mathrm{II}}^{\mathrm{A}}=R_{\mathrm{M} . \mathrm{A} . \mathrm{L} .}^{1}+R_{\mathrm{M} . \mathrm{A} . \mathrm{L} .}^{2} ;[\mathrm{dB}]
$$

where $R_{\text {MA.L. }}^{1}$ and $R_{\text {MA.L. }}^{2}$ - are the sound insulations for the first and for the second layers respectively, which are calculated by the formula (8) or (9).

Here, also, there will be the lowering of insulation because of the wave resonances in the air gap [20]. These resonances performing lays beyond the framework of this issue. The figure 4 depicts the conventionally insulation curve by the way "A", that is marked by figure "2"; and the plot of the resonance beginning, which is written by figure "3".

The graphs of insulation by the paths " $\mathrm{B}$ " and " $C$ " can be obtained on the base of concentrated parameters models application with the usage of transmittance and reflection coefficients at the junctions of considering constructions, but the engineer design permits to take into account the influence of indirect sound ways propagation only through the drawing of additional insulation curve for the insulation of construction layer by the mass action law formula. This additional insulation 


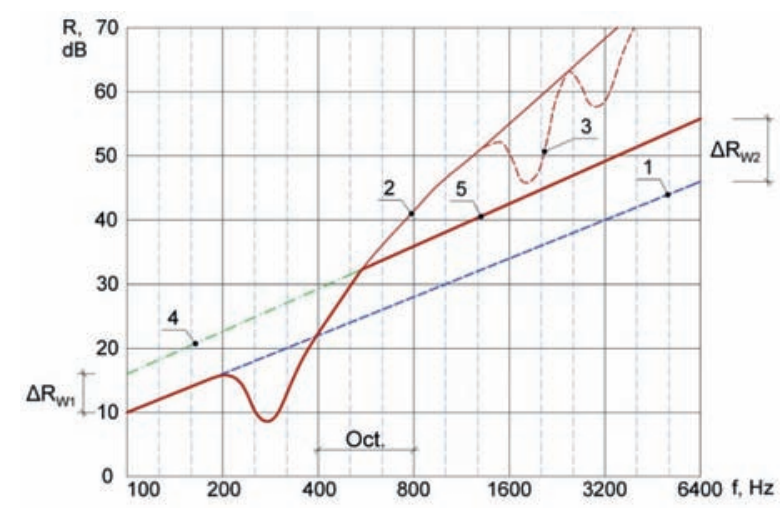

Figure 4. The sound insulation plot of insulation spectrum for the double layer envelope: 1 - is the graph by the mass action law formula (without taking into consideration the wave coincidence phenomenon); 2 - is the curve by the direct sound way propagation; 3 - is the direct way curve segment with insulation lowering due to the resonances; 4 -is the line of the additional insulation to the insulation of one layer defined by the mass action law formula;

5 - is the compound calculation curve appears due to the losses of oscillation energy in partition's construction layers at the points of their connection with the laterally adjoining walls and slabs, the line 4 , figure 4.

The additional insulation value varies from 6 to 12 [dB], the line 4, in the case of tight connections between the walls and slabs, which except hinges and resilient pads.

The resultant sound insulation plot is defined by that way, where the maximal sound transmittance is possible, like the compound curve "5" at the figure 4.

\section{RESULTS AND DISCUSSION}

For an instance, let's graph the insulation curve for the double layered inter-flat separate wall from the gypsum concrete, which is belonged to the typical design of a large-panel building by the Soviet

Table 1. The calculation of double-layered partition's insulationby the way of sound propagation " $A$ " for the example above

\begin{tabular}{|c|c|c|c|c|c|c|}
\hline Material & \multicolumn{6}{|c|}{ Gypsum concrete } \\
\hline Layer thickness, h, (m) & \multicolumn{6}{|c|}{0,08} \\
\hline Width of the air gap, a, (m) & \multicolumn{6}{|c|}{0,04} \\
\hline Surface density, $\mathrm{m},\left(\mathrm{kg} \cdot \mathrm{m}^{-2}\right)$ & \multicolumn{6}{|c|}{96} \\
\hline Current frequency, $\mathrm{f},(\mathrm{Hz})$ & 100 & 200 & 400 & 800 & 1600 & 3200 \\
\hline Density, $\rho,\left(\mathrm{kg} \cdot \mathrm{m}^{-3}\right)$ & \multicolumn{6}{|c|}{1200} \\
\hline Elasticity modulus, E, $\left(\mathrm{N} \cdot \mathrm{m}^{-2}\right)$ & \multicolumn{6}{|c|}{$7 \cdot 10^{9}$} \\
\hline Dilatational waves velocity, $c_{d i l},\left(\mathrm{~m} \cdot \mathrm{s}^{-1}\right)$ & \multicolumn{6}{|c|}{2465} \\
\hline Limiting frequency, $\mathrm{f}_{L}$, $(\mathrm{Hz})$ & \multicolumn{6}{|c|}{326} \\
\hline Ultimate frequency for the wall material, $f_{u l t . w},(\mathrm{~Hz})$ & \multicolumn{6}{|c|}{5135} \\
\hline$R_{\text {M.A.L.l }},(\mathrm{Hz})$ & 32 & 38 & & & & \\
\hline$R_{\text {M.A.L.2 }},(\mathrm{Hz})$ & & & 34 & 40 & 46 & 52 \\
\hline Ultimate frequency for the air gap, $f_{\text {ult.a }}(\mathrm{Hz})$ & \multicolumn{6}{|c|}{1417} \\
\hline Sound insulation, $R_{a}$, $(\mathrm{Hz})$ & 13 & 26 & 39 & 51 & 63 & 75 \\
\hline Free vibration frequency, $f_{0},(\mathrm{~Hz})$ & \multicolumn{6}{|c|}{43} \\
\hline Sound insulation, $R_{I}^{\mathrm{A}},(\mathrm{Hz})$ & 44 & 64 & 39 & 51 & & \\
\hline Sound insulation, $R_{I I}^{\mathrm{A}}$, $(\mathrm{Hz})$ & & & & & 91 & 103 \\
\hline
\end{tabular}


Setting Up a Problem of Air-Borne Sound Insulation Calculation For Double Layer Massive Enclosures on the Base of the Models With the Concentrated Parameters

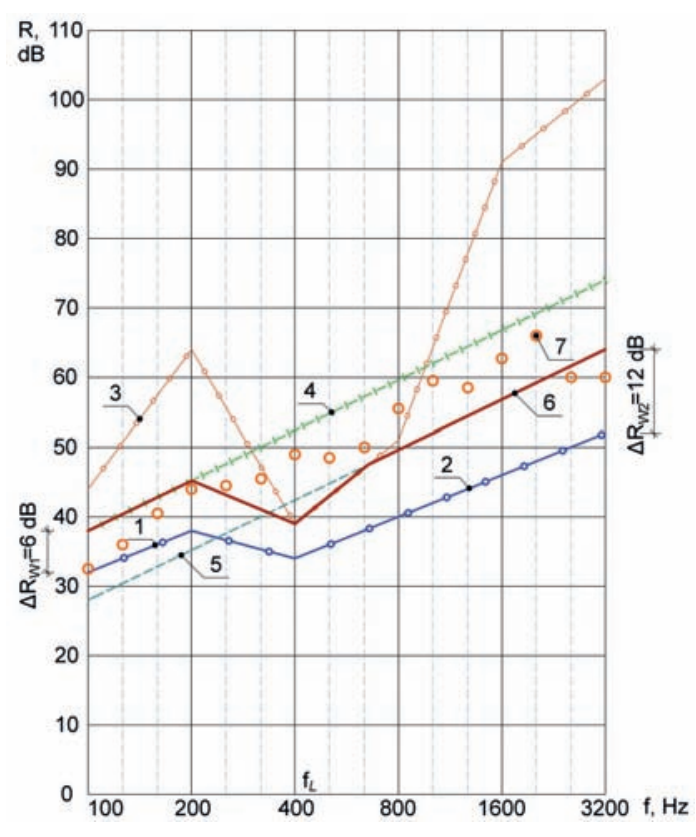

series 12335, [21]. The scheme of construction is similar to figure 2 , it has the layer's thickness, $h_{1}=$ $h_{2}=80 \mathrm{~mm}$, and the air gap width, $a=40 \mathrm{~mm}$. The main design parameters and computation results are represented in table 1 , the graphs are shown in the figure 5 .

The obtained compound curve $« 6 »$, figure 5 , doesn't entirely match with the curve of the field measurements « $7 »$, but the same time, it's insulation values lay rather close. The absence of full result coincidence of the given method with the experiment, can be explained by the number of factors, like unknown accurate information on the light-weight concrete mark, on conditions of fixing and measurement. Nevertheless, the gained in this and in another ones calculations results can witness about the theoretically correct calculation performing and about the verity of posing a task for application the acoustic models with the discrete parameters in case of double layer enclosures.

\section{CONCLUSIONS}

Finally, the following conclusions can be done: 1. It is necessary to take into consideration the direct and indirect ways of sound propagation in
Figure 5. The sound insulation plot of insulation spectrum for the double inter-flat wall from gypsum concrete with the layer thickness of $80 \mathrm{~mm}$ and air gap of $40 \mathrm{~mm}: 1$ - is the graph by the mass action law formula (8) for one layer's insulation up to the limit frequency; 2 - is the graph by the mass action law formula (9) for one layer's insulation after the limit frequency; 3 - is the direct way insulation curve; 4 - is the graph of additional insulation to the graph of one layer insulation by the mass action law before the limit frequency; 5 - is the graph of additional insulation to the graph of one layer insulation by the mass action law after the limit frequency; 6 -is the resultant curve; 7 - the field measured data

the process of calculation of the sound insulation for the double layered partitions.

2. While being treated with the directly air-born sound propagation calculation through the double layered enclosure, the two diapasons at the graph can be derived. They are: the frequency spectrum part, where the insulation is defined simultaneously by the structure's surface weight and by the dump and elastic qualities of the air; and the next one, where the insulation computed by the "Mass Action Law" in the frequency range above the ultimate frequency at the air gap for two layers summarily. 3 . The indirect way of sound propagation through the adjoining constructions at the engineer calculation can be taken into account by the drawing line of additional insulation to the graph of the one of the layer's insulation, obtained by the "Mass Action Law".

4. The application of the described above engineer method of the sound insulation's calculation with the usage of the models with the concentrated models approximately allows to find the sound insulation values for massive double layered building partitions across the entire standard frequency range.

It should be pointed out, that the represented calculation method need a further theoretical improvement and an experimental approbation. 


\section{REFERENCES}

1. Schelokov Y.A. Universal'naja formula rascheta zvukoizoljacii odnoslojnyh pregrad [Universal formula of calculation of sound insulation of single-layer barriers]. // Noise Theory and Practice, 2016, pp. 2-7 (in Russian).

2. Zdražilova N., Donova D., Skotnicova I. 2016 Analysis of Predictive Calculation Methods of Airborne Sound Insulation. // Applied Mechanics and Materials, 2016, Vol. 835, pp. 573-578.

3. Neubauer R.O., Kang J. Airborne sound insulation in terms of a loudness model. // Applied Acoustics, 2014, Vol. 85, pp. 34-45.

4. Ye Jun. Applying Immune Algorithems to the Calculation of Sound Insulation of Walls. // Applied Mechanics and Materials, 2014. Vols. 584-586, pp. 1853-1857.

5. Rodríguez-Molares A. A new method for auralisation of airborne sound insulation. // Applied Acoustics, 2013, Vol. 74, Issue 1, pp. 116-121.

6. Huang X., Yang Z., Yang Y. Prediction on Sound Insulation to a Single-Leaf Wall. // Advanced Materials Research, 2012, Vols. 594-597, pp. 2824-2827.

7. Zakharov A.V. conditions of continuity and the conservation laws of mechanics in noize passage's problems. // J. Scientific Review, 2016, Vol. 1.

8. Zakharov A.V. Revisiting the dependence of sound transmission on the angle of incidence at the interface between media or massive layer. // Journal of Industrial Pollution Control, 2017, Vol. 33, Issue 1, pp. 878-882.

9. Zakharov A.V. Obespechenie uslovij nerazryvnosti pri kosom prohozhdenii zvuka cherez massivnuju plastinu [Providing continuity conditions for oblique sound transmission through a massive plate]. // Innovacii i investicii, 2018, Vol. 12, pp. 163-166 (in Russian).

10. Zakharov A.V. Diskretnye modeli prohozhdenija voln pri raschetah zvukoizoljacii $\mathrm{v}$ zdanijah [Discrete models of passage of waves for calculation of sound insulation in buildings]. // Industrial and Civil Engineering, 2014, Vol. 11, pp. 50-53 (in Russian).

11. Zakharov A.V. The calculation of sound insulation of homogeneous enclosing structures. // The 3rd Nat. Conf. on the Noise Abatement. The reports (Varna: 2729.10.1973). 1973, Sofia, pp. 316.

12. Zakharov A. About some misunderstandings in the modern theory of the sound isolation and discrete models of sound transmission. // Applied Mechanics and Materials, 2013, Vol. 467, pp. 361.

13. Zakharov A.V. 2018 Discrete models upon calculation of soundproofing by solid plate. // International Journal of Pure and Applied Mathematics, 2018, Vol. 119, Issue 10, Special Issue C, pp. 439-443.

14. Saltykov I.P. An engineering estimation method of the sound insulation of massive partitions on the base of design model with lumped parameters. // IOP Conference Series: Materials Science and Engineering, 2020, Vol. 753, 032046.

15. Zakharov A.V., Saltykov I.P. The third frequency range of the sound insulation plot of the single-layer partitions. // IOP Conference Series: Materials Science and Engineering, 2020, Vol. 753, 032064.

16. Saltykov I.P. Sravnenie rezul'tatov raschjota zvukoizoljacii odnoslojnyh peregorodok na osnove modeli s sosredotochennymi parametrami s rezul'tatami tradicionnyh metodov rascheta [The comparison of sound insulation calculations results for single-layer partitions, which are based on concentrate parameters model, with the results of conventional calculation methods]. // Innovacii i investicii, 2020, Vol. 2, pp. 173-180 (in Russian).

17. Saltykov I.P. Raschet zvukoizoljacii tonkih peregorodok na osnove modeli s sosredotochennymi parametrami [Sound insulation design of the thin partitions on the base of concentrated parameters model]. 
Setting Up a Problem of Air-Borne Sound Insulation Calculation For Double Layer Massive Enclosures on the Base of the Models With the Concentrated Parameters

// Vestnik MGSU, 2020, Vol. 15, Issue 3, pp. 353-367 (in Russian).

18. Zaborov V.I. Teorija zvukoizoljacii ograzhdajushhih konstrukcij [The Theory of Sound Insulation of Enclosing Structures]. Moscow, Construction Literature Publishing, 1969, 186 pages (in Russian).

19. Kl'ukin I.N. Bor'ba s shumom i zvukovoj vibraciej na sudah [The Noise and Sound Vibration Abatement on the Ships]. Leningrad, Sudostroyeniye Publishing, 1971, 416 pages (in Russian).

20. Glushkov E., Glushkova N., Eremin A., Lammering R. Trapped modes and resonance wave transmission in a plate with a system of notches. // Journal of Sound and Vibration, 2018, Vol. 412, pp. 360-371.

21. Nikol'skiy V.N., Zaborov V.I. Zvukoizoljacija krupnopanel'nyh zdanij [The Sound Insulation of Large Panel Buildings]. Moscow, Construction Literature Publishing, 1964, 242 pages (in Russian).

\section{СПИСОК ЛИТЕРАТУРЫ}

1. Щелоков Ю.А. Универсальная формула расчета звукоизоляции однослойных преград. // NOISE Theory and Practice, 2016, c. 2-7.

2. Zdražilova N., Donova D., Skotnicova I. 2016 Analysis of Predictive Calculation Methods of Airborne Sound Insulation. // Applied Mechanics and Materials, 2016, Vol. 835, pp. 573-578.

3. Neubauer R.O., Kang J. Airborne sound insulation in terms of a loudness model. // Applied Acoustics, 2014, Vol. 85, pp. 34-45.

4. Ye Jun. Applying Immune Algorithems to the Calculation of Sound Insulation of Walls. // Applied Mechanics and Materials, 2014. Vols. 584-586, pp. 1853-1857.

5. Rodríguez-Molares A. A new method for auralisation of airborne sound insulation. // Applied Acoustics, 2013, Vol. 74, Issue 1, pp. 116-121.

6. Huang X., Yang Z., Yang Y. Prediction on Sound Insulation to a Single-Leaf Wall. //
Advanced Materials Research, 2012, Vols. 594-597, pp. 2824-2827.

7. Zakharov A.V. conditions of continuity and the conservation laws of mechanics in noize passage's problems. // J. Scientific Review, 2016, Vol. 1.

8. Zakharov A.V. Revisiting the dependence of sound transmission on the angle of incidence at the interface between media or massive layer. // Journal of Industrial Pollution Control, 2017, Vol. 33, Issue 1, pp. 878-882.

9. Захаров А.В. Обеспечение условий неразрывности при косом прохождении звука через массивную пластину. // Инновации и инвестиции, 2018, №6, с. 61-66.

10. Захаров А.В. Дискретные модели прохождения волн при расчетах звукоизоляции в зданиях. // Промышленное и гражданское строительство, 2012, №12, с. 20-22.

10. Zakharov A.V. Diskretnye modeli prohozhdenija voln pri raschetah zvukoizoljacii $\mathrm{v}$ zdanijah [Discrete models of passage of waves for calculation of sound insulation in buildings]. // Industrial and Civil Engineering, 2014, Vol. 11, pp. 50-53 (in Russian).

11. Zakharov A.V. The calculation of sound insulation of homogeneous enclosing structures. // The 3rd Nat. Conf. on the Noise Abatement. The reports (Varna: 2729.10.1973). 1973, Sofia, pp. 316.

12. Zakharov A. About some misunderstandings in the modern theory of the sound isolation and discrete models of sound transmission. // Applied Mechanics and Materials, 2013, Vol. 467, pp. 361.

13. Zakharov A.V. Discrete models upon calculation of soundproofing by solid plate. // International Journal of Pure and Applied Mathematics, 2018, Vol. 119, Issue 10, Special Issue C, pp. 439-443.

14. Saltykov I.P. An engineering estimation method of the sound insulation of massive partitions on the base of design model with lumped parameters. // IOP Conference Series: Materials Science and Engineering, 2020, Vol. 753, 032046. 
15. Zakharov A.V., Saltykov I.P. The third frequency range of the sound insulation plot of the single-layer partitions. // IOP Conference Series: Materials Science and Engineering, 2020, Vol. 753, 032064.

16. Салтыков И.П. Сравнение результатов расчёта звукоизоляции однослойных перегородок на основе модели с сосредоточенными параметрами с результатами традиционных методов расчета. // Инновации и инвестиции, 2020, №2, с. 173-180.

17. Салтыков И.П. Расчет звукоизоляции тонких перегородок на основе модели с сосредоточенными параметрами. // Вестник МГСУ, 2020, том 15, №3, с. 353-367.
18. Заборов В.И. Теория звукоизоляции ограждающих конструкций. - М.: Стройиздат, 1969. - $185 \mathrm{c}$.

19. Клюкин И.Н. Борьба с шумом и звуковой вибрацией на судах. - Л.: Судостроение, 1971. $-416 \mathrm{c}$.

20. Glushkov E., Glushkova N., Eremin A., Lammering $\mathbf{R}$. Trapped modes and resonance wave transmission in a plate with a system of notches. // Journal of Sound and Vibration, 2018, Vol. 412, pp. 360-371.

21. Никольский В.Н., Заборов В.И. Звукоизоляция крупнопанельных зданий. - М.: Стройиздат, 1964. - 242 с.
Arkadiy V. Zakharov, Professor, Ph.D., Department of Architecture, National Research Moscow State University of Civil Engineering; 26, Yaroslavskoe Shosse, Moscow, 129337, Russian; phone: +7 (495) 287-49-14 add. 3100; e-mail: zakharov.arkady@yandex.ru.

Ivan P. Saltikov, Senior Lecturer, Department of Architecture, National Research Moscow State University of Civil Engineering; 26, Yaroslavskoe Shosse, Moscow, 129337, Russian; phone +7 (495) 287-49-14 add. 3100; e-mail: vincesalt@mail.ru.

Захаров Аркадий Васильевич, кандидат технических наук, профессор кафедры «Архитектура», федеральное государственное бюджетное образовательное учрежде- ние высшего образования «Национальный исследовательский Московский государственный строительный университет»; 129337, Россия, г. Москва, Ярославское шоссе, дом 26; тел. +7(495)287-49-14 доб. 3100; e-mail: zakharov.arkady@yandex.ru.

Салтыков Иван Петрович, старший преподаватель кафедры «Архитектура», федеральное государственное бюджетное образовательное учреждение высшего образования «Национальный исследовательский Московский государственный строительный университет»; 129337, Россия, г. Москва, Ярославское шоссе, дом 26; тел.+7(495)287-49-14 доб.3100; e-mail: vincesalt@ mail.ru. 